\title{
PERSEPSI PASIEN PENGGUNA GIGI TIRUAN LEPASAN BERBASIS AKRILIK YANG MENGGUNAKAN JASA DOKTER GIGI DI KOTAMOBAGU
}

\author{
${ }^{1}$ Rifon I. Mokodompit \\ ${ }^{2}$ Krista V. Siagian \\ ${ }^{2}$ P. S. Anindita
}

\author{
${ }^{1}$ Kandidat Skripsi Program Studi Pendidikan Dokter Gigi Fakultas Kedokteran \\ ${ }^{2}$ Program Studi Pendidikan Dokter Gigi Fakultas Kedokteran \\ Universitas Sam Ratulangi Manado \\ Email: Rifonmokodompit@gmail.com
}

\begin{abstract}
Loss of teeth can be caused by various diseases such as caries and periodontal disease. Losing teeth can lead people to emotional impact as well as impaired functions of speaking, chewing, and aesthetics. The use of denture to replace missing teeth is important to avoid these impacts. This study aimed to determine patients' perception as users of removable acrylic based denture in Kotamobagu. This was a descriptive study with a cross sectional design. Population were 203 users of removable acrylic based denture at dentist services in Kotamobagu. Samples were 67 respondents obtained by using Solvin formula and simple random sampling method. In this study we used questionnaire consisted of 25 questions. The results showed that the patient's perception was in good category based on competence, access, needs, time, and budget.
\end{abstract}

Keywords: patient's perception, removable denture, dentist service

\begin{abstract}
Abstrak: Kehilangan gigi dapat disebabkan oleh berbagai penyakit seperti karies dan penyakit periodontal. Kehilangan gigi dapat menimbulkan dampak emosional serta terganggunya fungsi bicara, pengunyahan, dan estetika. Penggunaan gigi tiruan untuk menggantikan gigi yang hilang penting dilakukan untuk menghindari dampak tersebut. Penelitian ini bertujuan untuk mengetahui persepsi pasien pengguna gigi tiruan lepasan berbasis akrilik yang menggunakan jasa dokter gigi di Kotamobagu. Penelitian ini bersifat deskriptif dengan desain potong lintang. Populasi yaitu pasien pengguna gigi tiruan lepasan berbasis akrilik yang menggunakan jasa dokter gigi di Kotamobagu yang berjumlah 203 jiwa. Pengambilan sampel menggunakan rumus Slovin menghasilkan 67 sampel, dan metode pengambilan sampel dilakukan dengan simple random sampling. Studi ini menggunakan kuesioner yang berjumlah 25 pertanyaan. Hasil penelitian menunjukkan berdasarkan kompetensi, akses, kebutuhan, waktu, dan biaya persepsi pasien termasuk kategori baik.
\end{abstract}

Kata kunci : persepsi pasien, gigi tiruan lepasan, jasa dokter gigi

Gigi merupakan salah satu organ yang mempunyai peranan penting bagi tubuh manusia, diantaranya berfungsi untuk pengunyahan, estetik, dan berbicara. Idealnya setiap individu akan mempertahankan gigi permanen alamiahnya sepanjang hidup. Namun demikian gigi akan tanggal atau perlu dicabut dengan berbagai alasan. ${ }^{1}$ Kehilangan gigi dapat dialami siapa saja terlebih mereka yang kurang memperhatikan kebersihan gigi dan mulutnya. Kurangnya perhatian akan kebersihan gigi dan mulut dapat menyebabkan terjadinya karies, penyakit periodontal yang merupakan penyebab 
utama kehilangan gigi. Kehilangan gigi juga dapat terjadi akibat trauma atau karena alasan tertentu misalnya untuk keperluan perawatan ortodonti. ${ }^{2}$ Data dari WHO tahun 2012 tentang kesehatan mulut menunjukan bahwa 30\% populasi di dunia pada usia 6574 tahun mengalami kehilangan seluruh gigi. Persentase kehilangan gigi di Indonesia pada usia 35-44 tahun yaitu sebesar $0,4 \%$, semakin meningkat pada usia 65 tahun ke atas yaitu sebesar 17,6\%, sedangkan persentase kehilangan gigi di Sulawesi Utara yaitu 0,9\%.,

Kehilangan gigi yang masih cukup banyak menggambarkan besarnya kebutuhan akan perawatan prostodonsia. Perawatan prostodonsia dalam hal ini diperlukan untuk memperbaiki serta mempertahankan fungsi gigi melalui pembuatan gigi tiruan sebagai pengganti gigi asli yang telah hilang dan digunakan untuk mengembalikan fungsi fonetik, mastikasi, dan estetik. Didalam bidang kedokteran gigi, gigi tiruan terbagi atas gigi tiruan lepasan dan gigi tiruan cekat. ${ }^{5}$ Pembuatan gigi tiruan merupakan salah satu jenis pelayanan kesehatan yang dilakukan oleh dokter gigi. Banyak faktor yang mempengaruhi seseorang dalam pembuatan gigi tiruan oleh dokter gigi, antara lain yaitu kebutuhan masyarakat, kompetensi yang dimiliki seorang dokter gigi, biaya yang dikeluarkan, waktu dan akses terhadap pembuatan gigi tiruan oleh dokter gigi. ${ }^{5,6}$

Masyarakat di Kotamobagu yang kehilangan gigi geliginya telah menggunakan gigi tiruan dengan menggunakan pelayanan kesehatan yang dilakukan oleh dokter gigi. Masyarakat di Kotamobagu memiliki tingkat pendidikan yang berbeda-beda, sebagian besar masyarakat adalah lulusan sekolah menengah atas dengan keadaan status sosial ekonomi yang tergolong menengah kebawah. Hal tersebut mempengaruhi persepsi masyarakat tentang pembuatan gigi tiruan oleh dokter gigi. Berdasarkan latar belakang diatas, penulis tertarik untuk melakukan penelitian tentang persepsi pasien pengguna gigi tiruan lepasan berbasis akrilik yang menggunakan jasa dokter gigi di Kotamobagu.

\section{BAHAN DAN METODE PENELITIAN}

Penelitian ini bersifat deskriptif dengan desain cross sectional study. Penelitian ini dilaksanakan di Kotamobagu pada bulan Desember 2014. Populasi dalam penelitian ini yaitu pasien pengguna gigi tiruan lepasan berbasis akrilik yang menggunakan jasa dokter gigi sebanyak 203 orang. Metode pengambilan sampel menggunakan metode simple random sampling yang berjumlah 67 orang berdasarkan perhitungan Slovin.

Persepsi pasien yaitu cara pandang pasien yang mengalami kehilangan gigi terhadap pembuatan gigi tiruan oleh dokter gigi. Gigi tiruan lepasan adalah suatu alat tiruan yang dibuat untuk menggantikan gigi yang hilang dan jaringan sekitarnya, dan dapat dilepas sendiri oleh pasien dari dalam mulutnya. Jasa dokter gigi yaitu sebuah pelayanan yang ditujukan kepada pasien dalam memenuhi keinginan dan kebutuhan pasien, seluruh prosedur pembuatan gigi tiruan lepasan oleh dokter gigi untuk menggantikan gigi asli yang hilang. Pengukuran persepsi meliputi kebutuhan, kompetensi, biaya, waktu, dan akses. Penelitian ini menggunakan skala Guttman yaitu untuk mengetahui persepsi pasien digunakan 5 item pertanyaan, setiap pertanyaan diberi skor 2 untuk jawaban setuju dan skor 1 untuk jawaban tidak setuju sehingga mendapatkan jumlah skor tertinggi yaitu, 2x5x67= 670 sedangkan jumlah skor terendah $1 \times 5 \times 67=335$. Instrumen yang digunakan dalam penelitian ini yaitu kuesioner dan alat tulis menulis.

Pertimbangan etik permohonan untuk izin penelitian diperoleh dari persetujuan pihak kantor kecamatan di Kotamobagu dan dari responden yang diberikan kuesioner. Data diolah secara manual dan disajikan dalam bentuk tabel distribusi.

\section{HASIL PENELITIAN}

Berdasarkan hasil penelitian pada pasien pengguna gigi tiruan lepasan berbasis akrilik yang menggunakan jasa 
dokter gigi di Kotamobagu, subjek yang diteliti berjumlah 67 orang. Karakteristik subjek penelitian didistribusikan berdasarkan jenis kelamin, usia, tingkat pendidikan,pekerjaan, dan jenis gigi tiruan.

Tabel 1. Distribusi karakteristik responden berdasarkan jenis kelamin

\begin{tabular}{|c|c|c|}
\hline $\begin{array}{l}\text { Jenis } \\
\text { Kelamin } \\
\end{array}$ & $\begin{array}{c}\text { Jumlah } \\
\text { Responden (n) }\end{array}$ & $\%$ \\
\hline Laki- Laki & 28 & 41,8 \\
\hline Perempuan & 39 & 58,2 \\
\hline Jumlah & 67 & 100 \\
\hline
\end{tabular}

Tabel 1 menunjukkan bahwa responden perempuan lebih banyak yaitu 39 orang $(58,2 \%)$ dibandingkan dengan responden laki-laki yang berjumlah 28 orang $(41,8 \%)$ (Tabel 1$)$.

Tabel 2 menunjukkan bahwa sebagian besar responden berada pada kelompok usia 51-80 tahun yaitu sebanyak 38 responden (56,7\%) sedangkan pada kelompok usia 17-30 tahun sebanyak 3 responden $(4,5 \%)$.

Tabel 2. Distribusi karakteristik responden berdasarkan usia

\begin{tabular}{lcc}
\hline $\begin{array}{c}\text { Usia } \\
\text { (tahun) }\end{array}$ & $\begin{array}{c}\text { Jumlah } \\
\text { Responden (n) }\end{array}$ & $\%$ \\
\hline $17-30$ & 3 & 4,5 \\
$31-40$ & 5 & 7,5 \\
$41-50$ & 21 & 31,3 \\
$51-80$ & 38 & 56,7 \\
\hline Jumlah & 67 & 100 \\
\hline
\end{tabular}

Tabel 3 menunjukkan bahwa tingkat pendidikan responden yang paling banyak ialah SMA (Sekolah Menengah Atas) yaitu sebanyak 39 responden (58,2\%) dan yang tidak sekolah tidak ada responden sama sekali.

Tabel 4 menunjukkan bahwa pekerjaan dari responden yang paling banyak sebagai wiraswasta, yaitu 20 responden (29,8\%), dan hanya 3 responden (4,5\%) yang memiliki pekerjaan sebagai mahasiswa.

Tabel 5 menunjukkan bahwa sebagian besar responden merupakan pengguna gigi tiruan sebagian lepasan (GTSL) yaitu sebanyak 44 responden (65,7\%) dan yang merupakan pengguna jenis gigi tiruan penuh (GTP) 23 responden (34,3\%).

Tabel 3. Distribusi karakteristik responden berdasarkan tingkat pendidikan

\begin{tabular}{lcc}
\hline Pendidikan & $\begin{array}{c}\text { Jumlah } \\
\text { Responden (n) }\end{array}$ & $\%$ \\
\hline TS & - & - \\
SD & 3 & 4,5 \\
SMP & 5 & 7,5 \\
SMA & 39 & 58,2 \\
PT & 20 & 29,8 \\
\hline Jumlah & 67 & 100 \\
\hline
\end{tabular}

Tabel 4. Distribusi karakteristik responden berdasarkan pekerjaan

\begin{tabular}{lcc}
\hline Pekerjaan & $\begin{array}{c}\text { Jumlah } \\
\text { Responden (n) }\end{array}$ & $\%$ \\
\hline PNS & 17 & 25,4 \\
Wiraswasta & 20 & 29,8 \\
IRT & 15 & 22,4 \\
Mahasiswa & 3 & 4,5 \\
Pensiunan & 12 & 17,9 \\
\hline Jumlah & 67 & 100 \\
\hline
\end{tabular}

Tabel 5. Distribusi karakteristik berdasarkan jenis gigi tiruan

\begin{tabular}{lcc}
\hline $\begin{array}{l}\text { Jenis gigi } \\
\text { tiruan }\end{array}$ & $\begin{array}{c}\text { Jumlah } \\
\text { Responden } \\
\text { (n) }\end{array}$ & $\%$ \\
\hline GTP & 23 & 34,3 \\
GTSL & 44 & 65,7 \\
\hline Jumlah & 67 & 100 \\
\hline
\end{tabular}

Berdasarkan hasil perhitungan keseluruhan, maka persepsi pasien tentang:

1. Kebutuhan: memperoleh skor 626 dan termasuk kategori baik (Tabel 6).

2. Kompetensi: memperoleh skor 634 dan termasuk kategori baik (Tabel 7).

3. Biaya: memperoleh skor 575 dan termasuk kategori baik.

4. Akses: memperoleh skor 632 dan termasuk kategori baik.

5. Waktu: memperoleh skor 587 dan termasuk kategori baik. 
Mokodompit, Siagian, Anindita: Perserpsi pasien pengguna gigi tiruan ...

Tabel 6. Distribusi frekuensi penilaian persepsi pasien tentang kebutuhan gigi tiruan yang dibuat oleh dokter gigi

\begin{tabular}{|c|c|c|c|c|}
\hline No & Persepsi & Setuju & Tidak Setuju & $\begin{array}{l}\text { Total Skor } \\
\text { Penilaian }\end{array}$ \\
\hline 1 & $\begin{array}{l}\text { Gigi tiruan yang dibuat oleh } \\
\text { dokter gigi dapat menggantikan } \\
\text { fungsi (pengunyahan, bicara, } \\
\text { estetis) yang hilang. }\end{array}$ & 62 & 5 & 129 \\
\hline 2. & $\begin{array}{l}\text { Gigi tiruan yang dibuat oleh } \\
\text { dokter gigi dapat mempertahan- } \\
\text { kan jaringan mulut yang tersisa } \\
\text { serta memperbaiki gigitan } \\
\text { pasien. }\end{array}$ & 65 & 2 & 132 \\
\hline 3. & $\begin{array}{l}\text { Pembuatan gigi tiruan oleh } \\
\text { dokter gigi dapat segera } \\
\text { menjawab kebutuhan masyara- } \\
\text { kat yang kehilangan gigi }\end{array}$ & 52 & 15 & 119 \\
\hline 4. & $\begin{array}{l}\text { Pembuatan gigi tiruan oleh } \\
\text { dokter gigi dapat cepat } \\
\text { memulihkan rasa percaya diri } \\
\text { yang hilang. }\end{array}$ & 55 & 12 & 122 \\
\hline \multirow[t]{2}{*}{5.} & $\begin{array}{l}\text { Gigi tiruan yang dibuat oleh } \\
\text { dokter gigi dapat diterima } \\
\text { dengan baik dan rasa puas oleh } \\
\text { pasien. }\end{array}$ & 57 & 10 & 124 \\
\hline & Total Skor & & & 626 \\
\hline
\end{tabular}

Tabel 7. Distribusi frekuensi penilaian persepsi tentang kompetensi dokter gigi dalam pembuatan gigi tiruan

\begin{tabular}{llccc}
\hline No & Persepsi & Setuju & Tidak Setuju & $\begin{array}{c}\text { Total Skor } \\
\text { Penilaian }\end{array}$ \\
\hline 1. & $\begin{array}{l}\text { Dokter gigi mampu membuat gigi } \\
\text { tiruan sesuai kebutuhan pasien. }\end{array}$ & 60 & 7 & 127 \\
$\begin{array}{l}\text { Dokter gigi mampu melakukan } \\
\text { perawatan sebelum dan saat } \\
\text { pemasangan gigi tiruan. }\end{array}$ & 65 & 2 & 132 \\
$\begin{array}{l}\text { Dokter gigi yang berada di wilayah } \\
\text { Kotamobagu melayani pembuatan } \\
\text { gigi tiruan. }\end{array}$ & 54 & 13 & 121 \\
$\begin{array}{l}\text { Dokter gigi melayani pasien } \\
\text { pengguna gigi tiruan yang akan } \\
\text { melakukan kontrol setelah } \\
\text { pemasangan gigi tiruan. 60 }\end{array}$ & & 7 & 127 \\
$\begin{array}{l}\text { Dokter gigi membuat gigi tiruan } \\
\text { dengan menggunakan peralatan } \\
\text { medis yang lengkap dan steril } \\
\text { sehingga aman digunakan oleh } \\
\text { pasien. } 60\end{array}$ & & 7 & 127 \\
\hline Total Skor & & & \\
\hline
\end{tabular}


Tabel 8. Distribusi frekuensi penilaian persepsi pasien tentang biaya yang dikeluarkan dalam pembuatan gigi tiruan

\begin{tabular}{|c|c|c|c|c|}
\hline No & Persepsi & Setuju & Tidak Setuju & $\begin{array}{l}\text { Total Skor } \\
\text { Penilaian }\end{array}$ \\
\hline 1. & $\begin{array}{l}\text { Pembuatan gigi tiruan oleh dokter } \\
\text { gigi lebih mahal dibandingkan } \\
\text { dengan tukang gigi. } \\
\text { Pembuatan gigi tiruan oleh dokter }\end{array}$ & 64 & 3 & 131 \\
\hline 2. & $\begin{array}{l}\text { gigi menggunakan peralatan medis } \\
\text { yang lengkap dan steril sehingga } \\
\text { pasien memerlukan biaya lebih } \\
\text { banyak untuk pemeriksaan dan } \\
\text { pembuatan gigi tiruan. }\end{array}$ & 65 & 2 & 132 \\
\hline & $\begin{array}{l}\text { Dokter gigi sering memberikan resep } \\
\text { obat dalam melakukan perawatan }\end{array}$ & & & \\
\hline 3. & $\begin{array}{l}\text { sebelum dan setelah pemasangan } \\
\text { gigi tiruan sehingga pasien harus } \\
\text { menyediakan biaya lebih banyak } \\
\text { untuk pengobatan. }\end{array}$ & 34 & 33 & 101 \\
\hline & $\begin{array}{l}\text { Pembuatan gigi tiruan oleh dokter } \\
\text { gigi tidak asal-asalan dengan hasil }\end{array}$ & & & \\
\hline 4. & $\begin{array}{l}\text { yang memuaskan dan dapat diterima } \\
\text { dimulut pasien dengan baik, } \\
\text { sehingga pasien harus menyediakan } \\
\text { biaya lebih banyak. }\end{array}$ & 43 & 24 & 110 \\
\hline \multirow[t]{2}{*}{5.} & $\begin{array}{l}\text { Dokter gigi menawarkan tarif } \\
\text { pembuatan gigi tiruan sesuai jenis } \\
\text { gigi tiruan yang akan dibuat. }\end{array}$ & 54 & 13 & 121 \\
\hline & Total Skor & & & 575 \\
\hline
\end{tabular}

Tabel 9. Distribusi frekuensi penilaian persepsi pasien tentang waktu pembuatan gigi tiruan

\begin{tabular}{|c|c|c|c|c|}
\hline No & Persepsi & Setuju & Tidak Setuju & $\begin{array}{l}\text { Total Skor } \\
\text { Penilaian }\end{array}$ \\
\hline 1. & $\begin{array}{l}\text { Proses pembuatan gigi tiruan oleh } \\
\text { dokter gigi lebih lama diakibatkan } \\
\text { oleh tahap pembuatan yang } \\
\text { panjang. }\end{array}$ & 60 & 7 & 127 \\
\hline 2. & $\begin{array}{l}\text { Proses pembuatan gigi tiruan oleh } \\
\text { dokter gigi tepat waktu sesuai } \\
\text { dengan yang dijanjikan kepada } \\
\text { pasien pada awal pemeriksaan. } \\
\text { Proses pembuatan gigi tiruan oleh }\end{array}$ & 45 & 22 & 112 \\
\hline 3. & $\begin{array}{l}\text { dokter gigi membutuhkan waktu } \\
\text { lebih lama, namun bisa diterima } \\
\text { pasien dalam kondisi tidak } \\
\text { bergigi. }\end{array}$ & 47 & 20 & 114 \\
\hline 4. & $\begin{array}{l}\text { Proses pembuatan gigi tiruan oleh } \\
\text { dokter gigi terkadang lebih lama } \\
\text { karena terhambat oleh pengiriman } \\
\text { dari laboratorium. }\end{array}$ & 45 & 22 & 112 \\
\hline 5. & $\begin{array}{l}\text { Waktu yang dibutuhkan untuk } \\
\text { pembuatan gigi tiruan tergantung } \\
\text { jenis gigi tiruan apa yang akan } \\
\text { dibuat. }\end{array}$ & 55 & 12 & 122 \\
\hline & Total Skor & & & 587 \\
\hline
\end{tabular}


Tabel 10. Distribusi frekuensi penilaian persepsi pasien tentang akses yang ditempuh pasien ke dokter gigi

\begin{tabular}{llccc}
\hline No & Persepsi & Setuju & Tidak Setuju & $\begin{array}{c}\text { Total Skor } \\
\text { Penilaian }\end{array}$ \\
\hline 1. & $\begin{array}{l}\text { Tempat praktek dokter gigi } \\
\text { dapat dijangkau dengan cepat } \\
\text { dan mudah. }\end{array}$ & 57 & 10 & 124 \\
2. & & & 134 \\
dempat praktek dokter gigi & 67 & 0 & \\
kendaraan dijangkau dengan \\
(bentor) oleh masyarakat yang \\
tidak memiliki kendaraan \\
pribadi. \\
Tempat praktek dokter gigi di \\
$\begin{array}{l}\text { wilayah Kotamobagu ditunjang } \\
\text { oleh prasarana jalan yang } \\
\text { memadai. }\end{array}$
\end{tabular}

\section{BAHASAN}

Kehilangan gigi geligi dapat menyebabkan gangguan fungsi pengunyahan, bicara, dan estetis. Oleh karena itu, seseorang yang mengalami kehilangan gigi baik dibagian anterior maupun posterior tentu membutuhkan gigi tiruan untuk menggantikan gigi yang hilang. $^{7}$

Menurut peraturan menteri kesehatan nomor 512/Menkes/Per/IV/2007 tentang izin praktek dan pelaksanaan praktek kedokteran pada Bab 1 pasal 1 poin 7 menyebutkan pelayanan medis adalah pelayanan kesehatan yang diberikan oleh dokter dan dokter gigi sesuai kompetensi dan kewenangannya yang dapat berupa pelayanan promotif, preventif, diagnostik, konsultatif, kuratif dan rehabilitatif. $^{8}$ Pada dokter gigi pelayanan kesehatan tidak hanya melayani masyarakat yang sakit gigi tetapi masih banyak perawatan yang bisa diberikan oleh dokter gigi salah satunya yaitu pembuatan gigi tiruan.

Ekonomi merupakan salah satu faktor terpenting seseorang dalam mengambil suatu keputusan, apalagi mengenai pembuatan gigi tiruan pada dokter gigi bisa dikatakan cukup mahal. ${ }^{9}$

Data kondisi sosial ekonomi sebagian besar responden bermata pencaharian wiraswasta dan pegawai negeri sipil (PNS), serta berpendidikan SMA dan perguruan tinggi sehingga responden memaklumi akan biaya yang dikeluarkan cukup mahal untuk pembuatan gigi tiruan oleh dokter gigi. Hubungan pendidikan dengan kondisi sosial ekonomi responden mengubah tingkah laku, sikap, dan kepribadian seseorang sehingga sikap seseorang itu berkembang kearah yang lebih dinamis dan sempurna.

Penelitian yang dilakukan di oleh Teguh tentang tingkat kepuasan masyarakat pulau Kodingareng terhadap pelayanan kesehatan gigi dan mulut pada tahun 2011 di pulau Kodingareng Makassar menemukan bahwa tukang gigi bekerja lebih cepat sehingga pasien tidak menunggu terlalu lama karena rata-rata 
pasien yang berkunjung hanya dicetak dan dipasangkan gigi tiruan tanpa memeriksakan kondisi rongga mulut, sehingga akibat yang terjadi biasanya terdapat sisa akar di bawah gigi tiruan yang mengakibatkan peradangan jaringan gingival sedangkan pada dokter gigi pembuatan gigi tiruan lebih lama proses pembuatannya karena membutuhkan proses yang diawali dengan diagnosis, pencetakan rahang, perawatan persiapan, proses laboratorium, dan pemasangan gigi tiruan. ${ }^{10}$

Penelitian yang dilakukan pada masyarakat di Kotamobagu tentang persepsi responden terhadap akses ke tempat praktek dokter gigi sebagian responden berpersepsi tidak setuju akan keberadaan dokter gigi yang sangat minim di wilayah Kotamobagu tidak merata dan menjadi salah satu kendala dalam pembuatan gigi tiruan.

\section{SIMPULAN}

1. Persepsi pasien tentang kebutuhan dikategorikan baik dengan skor 626 .

2. Persepsi pasien tentang kompetensi dikategorikan baik dengan skor 634 .

3. Persepsi pasien tentang biaya dikategorikan baik dengan skor 575 .

4. Persepsi pasien tentang waktu dikategorikan baik dengan skor 587.

5. Persepsi pasien tentang akses dikategorikan baik dengan skor 632 .

\section{SARAN}

1. Bagi masyarakat agar dapat menimbulkan kesadaran tentang pentingnya pembuatan gigi tiruan oleh dokter gigi.

2. Perlu mengadakan penyuluhan kepada masyarakat tentang pentingnya pembuatan gigi tiruan yang menggunakan jasa dokter gigi oleh tenaga kesehatan.

3. Perlu dilakukan penelitian lebih lanjut dengan sampel yang lebih banyak dan metode yang berbeda.

\section{DAFTAR PUSTAKA}

1. Syamsudin E. Vestibulopasti Sebagian Persiapan Pembuatan Ilmu-Ilmu Kedokteran Gigi 2007:212

2. Kida IA, Astrom AN, Strand GV, Masalu JR. Clinical And Socio-Behavioral Correlates Of Tooth Loss: a study of older adults in Tanzania; 2006. [cited 24 Maret 2014]. Available from: URL: http://www.biomedcentral.com/14726831/6/5

3. Departemen Kesehatan Republik Indonesia. Laporan Riset Kesehatan Dasar Nasional [online].2007 [cited 2014 Apr 09] Avaible from: URL:http://www.riskesdas.litbang.depk es.go.id/download/TabelRiskesdas2007

4. World Health Organization. Oral Health. [serial online] 2012 [cited 4 Februari 2014]. Available from: URL: http:www.who.int/mediacentre/factshee ts/fs318/en/index.html.

5. Gunadi HA, Margo M, Burhan LK, Suryatenggara F, Setabudi 1. Buku ajar Ilmu Geligi Tiruan Sebagian Lepasan jilid1. Jakarta: Hipokrates;2012.

6. Notoatmodjo M. Pengantar Pendidikan Kesehatan dan Ilmu Perilaku. Jakarta: PT Rineka Cipta, 2003.

7. Shigli K, Hebbal M, Angadi GS. Attitudes towards replacement of teeth among patients at the Institute of Dental Science, Belgaum, India. J Dent Education 2007;71(11);1467-75.

8. Peraturan Menteri Kesehatan Nomor 512/MENKES/Per/iv/2007. Izin praktek dan pelaksanaan praktek kedokteran. Jakarta

9. Muhammad A, Azad AA, Ayub MM, Qureshi MA, Javed M. Denture hygiene habits in complete denture wearers at armed forces institute of dentistry. Armed Forces Institute of Dentistry. Pakistan [serial online] 2010: [cited 28 Desember 2014]. Available from:

URL:http://www.pafmj.org/showdetails .php?id=398\&t-0

10. Teguh $\mathbf{P}$. Tingkat kepuasan masyarakat pulau Kodingareng terhadap pelayanan kesehatan gigi dan mulut. Unhas repository [serial online] 2012 [cited 2014 Desember 28]. Available from: http://repository.unhas.ac.id/handle/123 456789/1039 